\title{
Article \\ Study of Local Duck Rations from Colocasia Esculenta Flour on Egg Production and Cholesterol Content
}

\section{Article Info \\ Article history : \\ Received September 11, 2020 \\ Revised September 27, 2020 \\ Accepted September 27, 2020 \\ Published September 30, 2020}

\section{Keywords :}

Colocasia esculenta, local duck, eggs production, cholesterol

\section{Zasmeli Suhaemi*, Sari Gando Hidayati}

${ }^{1}$ Department of Animal Husbandry, Faculty of Agriculture, Universitas Tamansiswa Padang, Indonesia

\begin{abstract}
Colocasia esculenta is the plants feed ingredients shown to reduce the cholesterol content of livestock products, such as in ducks. This study aims to examine the use of Colocasia esculenta Scho. plant in local duck rations on egg production, and the content of cholesterol and triglycerides. As a treatment in this study were the level of use of Colocasia esculenta meal (CM), 0\%, 5\%, 10\%, 15\% and $20 \%$, with 4 replications, which designed with a completely randomized design. As many as 80 ducks in the laying period were used, ranging in age from 19 to 30 weeks. The data obtained showed that an increasing level of CM up to $10 \%$ resulted in increased egg production, egg weight and decreased feed convertion ratio. Conversely, the blood and yolk total cholesterol and triglyceride content actually decreased until the level CM was $20 \%$. It was concluded that the use of CM up to a level of $10 \%$ could improve the performance of egg production, and the use of up to a level of $20 \%$ decreased the cholesterol and triglyceride content of blood and egg yolk. This is an important role about those subject for required healthy food for human nutrition.
\end{abstract}

This is an open acces article under the $C C-B Y$ license.

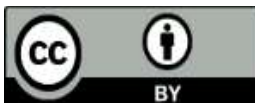

This is an open access article distributed under the Creative Commons 4.0 Attribution License, which permits unrestricted use, distribution, and reproduction in any medium, provided the original work is properly cited. (C2020 by author.

\section{Corresponding Author :}

Zasmeli Suhaemi

${ }^{1}$ Department of Animal Husbandry, Faculty of Agriculture,

Universitas Tamansiswa Padang, Indonesia

Email : emizasmeli@gmail.com

\section{Introduction}

In general, raising ducks on a commercial basis requires adequate dietary nutrition and supplementary feeding. The advantage of local ducks is the ability to survive in a poor environment and disease compared to chickens, also in utilizing low-quality feed, so that the cost of feed can be reduced. Local duck production also depends on its ability naturally or genetically. 
The ration is the most important in the field of animal husbandry, because it covers $70 \%$ of the total production costs (1). Meanwhile, feed conversion ratio is a measure of the coefficient of technical efficiency is often used, especially in the experimental development of poultry production.

One of the productions of poultry is an egg, which is an egg cell (ovum) that grows from a stem cell (oogonium) in the ovary (ovary) and is provided by poultry livestock as food material for embryo growth (2). Eggs are the center of concern by the community because they are rich in nutrients with relatively low prices. The egg productivity assessment of a group of ducks is to calculate daily production or DEP (Daily Egg Production). Egg productivity is good if the PTH value is more than $60 \%$. Ducks have a high DEP value if they are maintained for no more than 18 months of age.

The biggest obstacle for people in consuming duck eggs is their concern about their high cholesterol content (4-22). Cholesterol is an amphipathic lipid that is important in regulating membrane permeability and fluidity, and also as an outer layer of plasma lipoproteins (3). Lipids consist of triglycerides (neutral fat), phospholipids (lecithin), and cholesterol (23). However, high levels of local duck cholesterol often become a limiting factor for consumers to be careful in consuming local duck products. Cholesterol in the body that is excessive will be buried in the walls of blood vessels and cause a condition called atherosclerosis where blood vessel constriction occurs. This condition is the forerunner to the occurrence of heart disease and stroke in consumers who consume chicken meat (24).

One solution to reduce the cholesterol content of duck products is the taro leaves and taro. The stems on the taro leaves contain a substance called saponin, which can eliminate cholesterol and can be used as an antiseptic. Taro leaves contain protein, carbohydrates, fats, calcium, phosphorus, iron. In taro leaves also contain vitamins $\mathrm{A}, \mathrm{B} 1$, and $\mathrm{C}$ and taro leave also have polyphenols which function as antidotes to free radicals that damage cells in the body. Colocasia esculenta is also a chronic medicine that contains flavonoids and saponins which function as anti-bacterial agents (25).

Colocasia esculenta is a plant that contains many health benefits, namely as an antihypertensive, antidiabetic, antimicrobial and analgesic (26). Then reported that Colocasia esculenta contain various secondary metabolites. It is known that the Colocasia esculenta extract contains sugar, polyphenolic, terpenoid, saponin, alkaloid, glycoside, steroid or triterpenes, anthraquinone and coumarin components without cyanogenic. However, only tannins, glycosides and saponins without flavonoid can be obtained from the roots and stems of the Talas leaves. Besides, the phenolic compounds that have been identified in the Talas leaves are the flavonoid group. Then that Taro leaves were shown to contain high antioxidants and various bioactive substances that would improve health.

Research using taro leaves in mice has been shown that it could reduce lipid content, cholesterol content, triglycerides, Choleterol-High Density Lipoprotein and Cholesterol-Low Dencity Lipoprotein (27). This shows that the Colocasia esculenta Scho. plant is thought to be able to reduce the cholesterol content of local duck products, thereby eliminating the limiting factor for people who want to consume local duck eggs. This study aims to examine the use of Colocasia esculenta Scho. plant in local duck rations on egg production, and the content of cholesterol and triglycerides blood and local duck eggs.

\section{Experimental Section}

This study used 80 local ducks, aged 19 weeks to 27 weeks, which were kept in a battery system enclosure. This research used of stems and leaves of Colocasia esculenta Scho. in the form of flour. Colocasia esculenta Scho. is already wide enough to be chopped $1 \mathrm{~cm}$ long, then dried in the sun to 
dry and easily destroyed. Dry stems and leaves of Colocasia esculenta Scho, then milled until smooth and sifted with a $1 \mathrm{~mm}$ sieve mesh size, and than called Colocasia esculenta Scho. Meal $(\mathrm{CM})$. The process described as picture 1 .

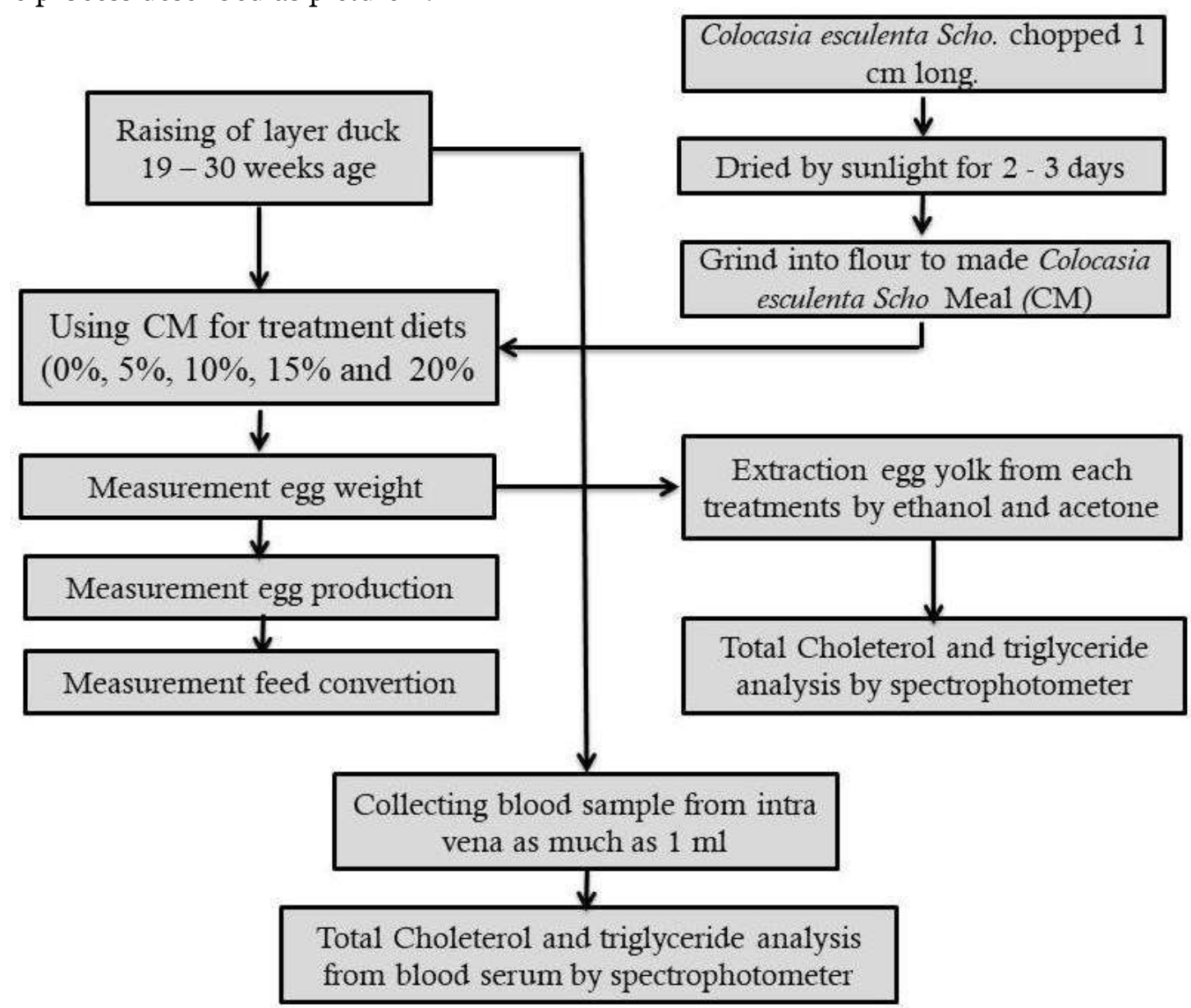

Figure 1. Research implementation diagram

The ingredients of the ration used are listed in Table 1, with the composition of the research ration as listed in Table 2. The ration was given in the same amount of $150 \mathrm{~g} / \mathrm{e} / \mathrm{d}$.

Table 1. The content of food substances rations

\begin{tabular}{lcrrrr}
\hline \multicolumn{1}{c}{ Food Substance } & Conch Flour $^{*}$ & Fine Bran $^{*}$ & Ground Corn $^{*}$ & Concentrate & CM $^{*}$ \\
\hline Dry matter (\%) & 87,37 & 90,70 & 91,29 & 89,63 & 73,00 \\
Crude Protein(\%) & 41,06 & 12,04 & 8,60 & 34,00 & 4,10 \\
Crude Fiber(\%) & 18,78 & 12,00 & 2,70 & 5,00 & 12,30 \\
Crude Fiber(\%) & 1,30 & 1,70 & 4,20 & 3,00 & 2,10 \\
ME(kcal/kg) & 2600,00 & 1630,00 & 3420,00 & 2600,00 & 71,00 \\
Calsium(\%) & 10,14 & 0,20 & 1,00 & 12,00 & 0,30 \\
Phospor(\%) & 0,49 & 1,00 & 2,56 & 1,20 & 0,04 \\
\hline
\end{tabular}

Note : CM (Colocasia esculenta Meal)

Source: "Poultry nutrition laboratory analyzed (2014) 
Table 2. Composition and content of rations

\begin{tabular}{lrrrrr}
\hline \multirow{2}{*}{ Details } & \multicolumn{5}{c}{ Treatment } \\
\cline { 2 - 5 } & \multicolumn{1}{c}{ P1 } & \multicolumn{1}{c}{ P2 } & \multicolumn{1}{c}{ P3 } & \multicolumn{1}{c}{ P4 } & \multicolumn{1}{c}{ P5 } \\
\hline Ground corn(\%) & 56,50 & 56,50 & 57,50 & 57,00 & 58,00 \\
Fine bran(\%) & 12,50 & 12,00 & 10,50 & 11,00 & 9,00 \\
Soybean meal(\%) & 21,00 & 20,50 & 21,00 & 19,00 & 20,50 \\
Fish flour (\%) & 10,00 & 10,50 & 10,00 & 11,50 & 10,00 \\
CM (\%) & 0,00 & 5,00 & 10,00 & 15,00 & 20,00 \\
ME (kkal/kg) & 2645,38 & 2683,66 & 2606,04 & 2604,73 & 2583,04 \\
Crude protein(\%) & 17,03 & 17,06 & 16,90 & 17,13 & 17,53 \\
Crude fat (\%) & 2,93 & 3,11 & 3,13 & 3,26 & 3,13 \\
Crude fiber(\%) & 5,72 & 5,08 & 5,07 & 4,62 & 4,83 \\
Ca (\%) & 3,45 & 3,82 & 3,94 & 4,35 & 4,28 \\
P (\%) & 1,65 & 1,68 & 1,63 & 1,63 & 1,48 \\
\hline
\end{tabular}

Calculate based on Table 1

The design used was Completely Randomized Design (CRD) with 5 treatments using CM $(0 \% ; 5 \% ; 10 \% ; 15 \%$; and $20 \%)$, each treatment repeated 4 times. Significant analysis results were carried out with the Duncan Multiple Range Test (DMRT).

The variables analyzed in this study were the performance of duck eggs production. Total cholesterol and triglycerides blood and eggs. Obtained from duck blood serum taken through a vein in the pectoralis vein as much as $1 \mathrm{ml}$. Whereas Total Cholesterol and triglyceride yolk was obtained from egg yolk extract using ethanol and technical acetone. Than analyzed using the Microlab 300 Spectrophotometer.

\section{Results and Discussion}

The results of studies on eggs weight, eggs production, and feed conversion ratio are as shown in Table 3.

Table 3. Average egg weight, egg production, and feed conversion ratio

\begin{tabular}{crrrrrr}
\hline Treatment & Egg weight (g) & sdev & $\begin{array}{c}\text { Egg } \\
\text { production } \\
(\%)\end{array}$ & sdev & $\begin{array}{c}\text { Feed } \\
\text { conversion } \\
\text { ratio }\end{array}$ & sdev \\
\hline $0 \% \mathrm{CM}$ & $60,075^{\mathrm{a}}$ & 3,45 & $69,65^{\mathrm{ab}}$ & 7,57 & $4,15^{\mathrm{b}}$ & 3,11 \\
$5 \% \mathrm{CM}$ & $60,425^{\mathrm{a}}$ & 4,79 & $73,81^{\mathrm{b}}$ & 8,21 & $4,25^{\mathrm{ab}}$ & 4,02 \\
$10 \% \mathrm{CM}$ & $64,12^{\mathrm{b}}$ & 3,91 & $75,92^{\mathrm{b}}$ & 7,52 & $3,92^{\mathrm{b}}$ & 3,66 \\
$15 \% \mathrm{CM}$ & $60,76^{\mathrm{a}}$ & 6,71 & $67,45^{\mathrm{a}}$ & 8,40 & $4,66^{\mathrm{a}}$ & 4,83 \\
$20 \% \mathrm{CM}$ & $58,475^{\mathrm{a}}$ & 6,27 & $63,69^{\mathrm{a}}$ & 7,84 & $4,73^{\mathrm{a}}$ & 5,10 \\
\hline
\end{tabular}

Different superscripts in the same column mean significantly different $(\mathrm{P}<0,05)$

The minimal average weight of eggs that used CM in their diets were in $20 \%$ level using CM and the higest was in level $10 \%$ using CM. It is the same with egg production. The lowest feed convertion was in level 10\% using CM, and the highest was in $20 \%$ level using CM to. The average weight and egg production indicate that the increased use of $\mathrm{CM}$ in the ration to the level of $10 \%$ will increase production, but decrease in the use of $15 \%$ and $20 \%$. The use of CM has also been proven to significantly reduce the conversion of local duck rations to a level of $10 \%$. This can be 
caused by the presence of anti-nutrient content such as Tannin, anthocyanin, and saponin in CM. It was reported that the ethanol extract of CM have phenolic, anthocyanin, tannin, saponin, terpenoid, anthraquinone, alkaloid, flavonoid, sterol, carbohydrate, vitamin A and C (28) .

Analysis Variance from egg weight, eggs production and feed conversion ratio obtained significantly different $(\mathrm{P}<0.05)$. This is because $\mathrm{CM}$ are known to contain bioactive substances and antioxidants (26), which can improve livestock health and increase production and are more efficient in utilizing feed, but at the $15 \%$ level, there is a decrease in egg weight and production, as well as an increase in feed conversion ratio.

Table 4 is the result of Total Cholesterol and Trigliceride content analysis on local duck blood and yolk based on the treatment. Total Cholesterol and Trigliceride local egg duck blood, was obtained from blood serum. In other hand, Total Cholesterol and Trigliceride duck eggs is obtained from yolk, which extract by acetone and ethanol.

Table 4. Total cholesterol (TC) and Triglycerides (Tgs) content of blood serum (mg/dl) and yolk (mg/100g)

\begin{tabular}{ccccccccc}
\hline \multirow{2}{*}{ Treatment } & $\begin{array}{c}\text { Blood } \\
\text { TC }\end{array}$ & stdev & $\begin{array}{c}\text { Yolk } \\
\text { TC }\end{array}$ & stdev & $\begin{array}{c}\text { Blood } \\
\text { Tgs }\end{array}$ & stdev & $\begin{array}{c}\text { Yolk } \\
\text { Tgs }\end{array}$ & stdev \\
\hline $0 \% \mathrm{CM}$ & $165,60^{\mathrm{a}}$ & 6,11 & $204,63^{\mathrm{a}}$ & 3,27 & $191,75^{\mathrm{a}}$ & 8,14 & $200,70^{\mathrm{a}}$ & 28,89 \\
$5 \% \mathrm{CM}$ & $163,10^{\mathrm{a}}$ & 1,31 & $156,55^{\mathrm{c}}$ & 9,12 & $162,88^{\mathrm{b}}$ & 3,56 & $187,43^{\mathrm{b}}$ & 23,26 \\
$10 \% \mathrm{CM}$ & $135,23^{\mathrm{c}}$ & 3,58 & $148,88^{\mathrm{c}}$ & 2,69 & $135,40^{\mathrm{c}}$ & 4,05 & $173,00^{\mathrm{c}}$ & 28,12 \\
$15 \% \mathrm{CM}$ & $139,20^{\mathrm{b}}$ & 5,39 & $172,13^{\mathrm{b}}$ & 3,99 & $142,58^{\mathrm{c}}$ & 2,39 & $177,65^{\mathrm{c}}$ & 11,16 \\
$20 \% \mathrm{CM}$ & $138,30^{\mathrm{b}}$ & 7,43 & $172,43^{\mathrm{b}}$ & 8,70 & $142,33^{\mathrm{c}}$ & 2,36 & $180,35^{\mathrm{b}}$ & 17,54 \\
\hline
\end{tabular}

Different superscripts in the same column show significantly different $(\mathrm{P}<0,05)$

The lowest total cholesterol blood results were at the use of CM in 10\% level, and the highest was at the use of $\mathrm{CM}$ in $0 \%$ level. These results are also same with the blood triglyceride content. Cholesterol is a sterol fat found in cell membranes and circulated in blood plasma. Sterols are molecules consisting of rings of carbon atoms that are linked with side chains of bound carbon, hydrogen and oxygen (29).

The results of Table 4 illustrate that the increasing use of CM in the ration, it will reduce the average TC and Tgs $(\mathrm{P}<0.01)$, although it increased again at the level of $15 \%$ but not significantly different $(\mathrm{P}>0.05)$ between the level of $10 \%$ up to $20 \%$. Likewise, the content of egg cholesterol was also very significantly decreased $(\mathrm{P}<0.01)$, along with with an increase in the use of Colocasia esculenta flour, but the results of the DMRT showed no significant difference $(P>0.05)$ between the use of CM $5 \%$ to $20 \%$

This shows that the use of $\mathrm{CM}$ has the opportunity to produce low cholesterol duck products due to the presence of saponin substances that function to reduce cholesterol. Stalks on taro leaves contain a substance called saponin, which can eliminate cholesterol and as an antiseptic (6). Colocasia esculenta sho. contain various secondary metabolites. It is known that the Colocasia esculenta extract contains components of sugar, polyphenolic, terpenoids, saponins, alkaloids, glycosides, steroids (30).

\section{Conclusion}

The use of Colocasia esculenta in local duck rations, can increase egg production and reduce feed conversion ratio up to a level of $10 \%$, as well as reduce the total cholesterol and triglycerides content of blood and eggs. 


\section{References}

1. Pal V, Gobade M, Kanth K, Thakur A, Maini S.(2013) Comparative Efficacy of Supplementation Of Herbal Liver Tonic Products On Growth And Performance In Broilers. Int J Adv Sci Tech Res [Internet]. 6(7). Available from: http://www.rspublication.com/ijst/index.html

2. Kurtini T, Nova K, Septinova D.(2011). Produksi Ternak Unggas. Bandar Lampung: Anugrah Utama Raharja (AURA) Universitas Lampung.

3. Botham KM, Mayes PA.(2012). Harper's Illustrated Biochemistry: Cholesterol Synthesis, Transpor \& Excretion. Amerika Serikat: McGraw Hill.

4. Alonso L, Calvo MV, Fontecha J. (2019). The Influence of beta-Cyclodextrin on the Reduction of Cholesterol Content in Egg and Duck Liver Pate. Foods.8(7).

5. Bair CW, Marion WW. (1978). Yolk cholesterol in eggs from various avian species. Poultry science.57(5):1260-5.

6. Bathgate R, Maxwell WM, Evans G. (2006). Studies on the effect of supplementing boar semen cryopreservation media with different avian egg yolk types on in vitro post-thaw sperm quality. Reproduction in domestic animals = Zuchthygiene.41(1):68-73.

7. Braun CM, Frank N, Latour MA. (2002). The circulating levels of lipoproteins in embryos and newly hatched ducklings change with parental age. Biology of the neonate.82(2):128-33.

8. Chartrin P, Bernadet MD, Guy G, Mourot J, Hocquette JF, Rideau N, et al. (2007). Do age and feeding levels have comparable effects on fat deposition in breast muscle of mule ducks? Animal : an international journal of animal bioscience.1(1):113-23.

9. Du X, Liu Y, Lu L, Wang W, Zeng T, Tian Y, et al. (2017). Effects of dietary fats on egg quality and lipid parameters in serum and yolks of Shan Partridge Duck. Poultry science.96(5):1184-90.

10. Du X, Ren JD, Xu XQ, Chen GH, Huang Y, Du JP, et al. (2019). Comparative transcriptome analysis reveals genes related to the yolk ratio of duck eggs. Animal genetics.50(5):484-92.

11. Eastin WC, Jr., O'Shea TJ. (1981). Effects of dietary nickel on mallards. Journal of toxicology and environmental health.7(6):883-92.

12. Ganesan P, Kaewmanee T, Benjakul S, Baharin BS. (2014). Comparative Study on the Nutritional Value of Pidan and Salted Duck Egg. Korean journal for food science of animal resources.34(1):1-6.

13. Hidanah S, Nazar DS, Safitri E. (2018). The improvement of eggs quality of Mojosari duck (Anas javanica) with soybean husk fermentation using cellulolytic bacteria of Spodoptera litura. Veterinary world.11(5):720-5.

14. Liu WM, Zhang J, Lu LZ, Shi FX, Niu D, Wang DL, et al. (2011). Effects of perilla extract on productive performance, serum values and hepatic expression of lipid-related genes in Shaoxing ducks. British poultry science.52(3):381-7.

15. Ruan D, Fouad AM, Fan QL, Chen W, Xia WG, Wang S, et al. (2018). Effects of corn dried distillers' grains with solubles on performance, egg quality, yolk fatty acid composition and oxidative status in laying ducks. Poultry science.97(2):568-77. 
16. Ruan D, Fouad AM, Zhang YN, Wang S, Chen W, Xia WG, et al. (2019). Effects of dietary lysine on productivity, reproductive performance, protein and lipid metabolism-related gene expression in laying duck breeders. Poultry science.98(11):5734-45.

17. Ruan D, Lin YC, Chen W, Wang S, Xia WG, Fouad AM, et al. (2015). Effects of rice bran on performance, egg quality, oxidative status, yolk fatty acid composition, and fatty acid metabolism-related gene expression in laying ducks. Poultry science.94(12):2944-51.

18. Turk DE, Barnett BD. (1971). Cholesterol content of market eggs. Poultry science.50(5):1303-6.

19. Vadehra DV, Bain JM, Burley RW. (1977). Lipid-protein globules of avian egg yolk. Isolation and properties of globules stable in concentrated sodium chloride solution. The Biochemical journal.166(3):619-24.

20. Wang Z, Meng G, Bai Y, Liu R, Du Y, Su L. (2017). Comparative transcriptome analysis provides clues to molecular mechanisms underlying blue-green eggshell color in the Jinding duck (Anas platyrhynchos). BMC genomics.18(1):725.

21. Yang SC, Chen KH. (2001). The oxidation of cholesterol in the yolk of selective traditional Chinese egg products. Poultry science.80(3):370-5.

22. Yen CF, Jiang YN, Shen TF, Wong IM, Chen CC, Chen KC, et al. (2005). Cloning and expression of the genes associated with lipid metabolism in Tsaiya ducks. Poultry science.84(1):67-74.

23. Garaha KC. Kolesterol. Jakarta: PT Elex Media Komputido; 2010.

24. Ma H.(2006). Cholesterol and Human Health. J Am Sci. 2(1):46-50.

25. Khairany N, Idiawati N, Wibowo MA.(2015). Analisis Sifat Fisik dan Kimia Gel Esktrak Etanol Daun Talas (Colocasia esculenta (L.) Schott). JKK.;4(2):81-8.

26. Yeap SK, Ho WY, Beh BK, Liang WS, Ky H, Hadi A, et al.(2010). Ethnomedical Used Green Vegetable With Multiple Bio- Activities. J Med Plants Res.;4(25):2787-812.

27. Adaramoye OA, Akintayo O, Achem J, Fafunso MA. (2008). Lipid-lowering effects of methanolic extract of Vernonia amygdalina leaves in rats fed on high cholesterol diet. Vasc Health Risk Manag [Internet]. [cited 2018 Nov 30];4(1):235-41. Available from: http://www.ncbi.nlm.nih.gov/pubmed/18629374

28. Kumawat N, Chaudari S, Wani N, Deshmukh T, Patil V. (2010). Antidiabetic Activity of Ethanol Extract of Colocasi esculenta Leaves in Alloxan Induced Diabetic Rats. . Int J PharmTech Reasearch.;2(2):1246-9.

29. Sizer F, Whitney EN. (2008). Nutrition: Concepts and Controversies. USA: Chengage Leaming;.

30. Biren N., Nayak B., Bhatt S., Jalalpure S., Seth A. (2007). The Anti-Inflamatory Activity of The Leaves of Colocasia esculenta. SPJ.;15:3-4. 